\title{
Classificatie van eigen en vreemd vermogen bij toepassing van Nederlandse grondslagen
}

\author{
Kees Camfferman, Frans van der Wel
}

Received 26 September $2019 \quad$ Accepted 24 October $2019 \quad$ Published 11 December 2019

\section{Samenvatting}

Bij toepassing van Nederlandse grondslagen wordt het onderscheid tussen eigen en vreemd vermogen in de enkelvoudige jaarrekening gemaakt op basis van de juridische vorm en in de geconsolideerde jaarrekening op basis van economische realiteit. De invulling van het begrip economische realiteit is ontleend aan IFRS, waar de op balansdatum bestaande verplichting centraal staat. Het onderzoek waarvan dit artikel verslag doet laat zien dat zich bij veel ondernemingen geen complexe classificatievragen voordoen en er geen verschil bestaat tussen juridische en economische vorm. De jaarrekeningen van ondernemingen waar deze vraag mogelijk wel relevant is geven hierover doorgaans slechts weinig informatie. De RJ laat, in navolging van IFRS, de mogelijkheid open om bepaalde financiële instrumenten die in termen van economische realiteit het karakter hebben van verplichtingen toch als eigen vermogen te presenteren. Hoewel het onderzoek aannemelijk maakt dat dergelijke 'puttable' eigenvermogensinstrumenten met enige regelmaat voorkomen bij coöperaties en professionele dienstverleners met een partnerstructuur, geeft de verslaggeving hierover betrekkelijk weinig inzicht.

\section{Relevantie voor de praktijk}

Omdat classificatie als eigen of vreemd vermogen in veel situaties niet complex is, is er een risico dat het vraagstuk onderschat wordt. Dit artikel helpt verslaggevende ondernemingen en accountants om alert te zijn op situaties die wel om zorgvuldige afweging en duidelijke toelichting vragen.

\section{Trefwoorden}

externe verslaggeving, eigen vermogen, vreemd vermogen

\section{Inleiding}

In dit artikel komt aan de orde hoe in de verslaggeving van Nederlandse ondernemingen wordt gerapporteerd over de classificatie van financiële instrumenten als eigen of vreemd vermogen. Wij richten ons op niet-beursgenoteerde ondernemingen die zowel in de enkelvoudige als in de geconsolideerde jaarrekening de Nederlandse grondslagen toepassen. Een belangrijk aandachtspunt hierbij is de bestaande RJ-bepaling dat in de enkelvoudige jaarrekening de juridische vorm van financiële instrumenten bepalend is voor de classificatie als eigen dan wel vreemd vermogen, terwijl deze classificatie in de ge- consolideerde jaarrekening op basis van de economische realiteit plaatsvindt.

Door ons te richten op niet-genoteerde ondernemingen geven wij met dit artikel een aanvulling op eerdere literatuur waarin aspecten van de classificatie eigen/vreemd vermogen onder Nederlandse grondslagen zijn behandeld voor wat betreft de enkelvoudige jaarrekening van beursgenoteerde ondernemingen. Zie hiervoor bijvoorbeeld Vergoossen (2006) inzake de invloed van IFRS op nettoresultaat en eigen vermogen, en Backhuijs et al. (2017) over de presentatie van other comprehensive income. 
Het empirisch onderzoek waarvan in dit artikel verslag wordt gedaan heeft een verkennend karakter en bestaat uit twee delen. In het eerste deel onderzoeken wij de jaarrekeningen van 60 willekeurig gekozen middelgrote en grote rechtspersonen. De willekeurige selectie is bedoeld om een indruk te krijgen van de mate waarin zich de classificatieproblematiek bij deze groep voordoet, en of hierover in de jaarrekening voldoende duidelijkheid wordt verschaft.

Het tweede deel van het onderzoek richt zich op de jaarrekeningen van 20 coöperaties en ondernemingen voor zakelijke dienstverlening (te weten accountants- en advocatenkantoren). Deze groep is geselecteerd met de verwachting dat zich hier wel een specifieke problematiek kan voordoen, namelijk de mogelijkheid van uittredende leden of partners om hun kapitaalbelang aan de onderneming terug te verkopen. In dat geval is mogelijk sprake van financiële instrumenten die de juridische vorm hebben van eigen vermogen, maar feitelijk een verplichting vormen. Deze instrumenten staan bekend als 'puttable' eigenvermogensinstrumenten. Ook hier is de vraag of de jaarrekeningen in voldoende mate duidelijk maken of deze instrumenten zich voordoen, en hoe zij dan zijn verwerkt.

Dit artikel is als volgt opgebouwd. In paragraaf 2 bespreken wij de achtergronden en hoofdlijnen van de huidige Nederlandse wet- en regelgeving. In paragraaf 3 zetten wij de selectie van de steekproeven uiteen. Paragraaf 4 bevat een bespreking van de verslaggeving door de steekproef van 60 willekeurig gekozen ondernemingen, gevolgd door paragraaf 5 over de jaarrekeningen van de coöperaties en de zakelijke dienstverleners. Het artikel wordt afgesloten met enkele conclusies en aanbevelingen in paragraaf 6 .

\section{Het classificatievraagstuk in wet- en regelgeving}

\subsection{Het vraagstuk in context}

De problematiek van het onderscheid tussen eigen en vreemd vermogen kan zich voordoen wanneer de financiële structuur van een onderneming uit complexer onderdelen bestaat dan gewone aandelen en leningen met eenduidig te bepalen rente- en aflossingsverplichtingen. Wanneer discussie mogelijk is of een bepaalde balanspost als eigen of vreemd vermogen geclassificeerd moet worden, is dit al snel geen vrijblijvend vraagstuk meer. Uit de structuur van de jaarrekening volgt dat classificatie meestal gevolgen zal hebben voor de gerapporteerde winst. Afhankelijk van wettelijke bepalingen kan dit gevolgen hebben voor de mogelijkheid van winstuitkering. In het algemeen wordt de verhouding eigen/vreemd vermogen gezien als een belangrijk kengetal.

Deze classificatievraag is universeel, en de International Financial Reporting Standards (IFRS) zijn dan ook een belangrijk referentiepunt voor de Nederlandse wet- en regelgeving. Sinds 1995 wordt dit onderwerp behandeld in IAS 32 Financial Instruments: Presentation. Het uitgangspunt daarbij is dat aan de creditzijde van de balans slechts twee soorten posten kunnen voorkomen, te weten eigen vermogen en vreemd vermogen. Tussenvormen zijn uitgesloten. Daarbij is alleen vreemd vermogen positief gedefinieerd, en wel in termen van op balansdatum bestaande verplichtingen. Eigen vermogen is slechts het rekenkundige saldo van activa en verplichtingen. Dit algemene uitgangspunt wordt concreet gemaakt doordat de afgrenzing tussen eigen of vreemd vermogen wordt behandeld in termen van financiële instrumenten. Eigenen vreemdvermogensinstrumenten behoren tot dezelfde algemene familie van financiële instrumenten, contracten die aan de houder bepaalde financiële rechten verlenen. Voor zover deze rechten voor de uitgevende onderneming op balansdatum bestaande verplichtingen bevatten is het instrument een financiële verplichting. Slechts wanneer het instrument 'het overblijvende belang omvat in de activa van een entiteit, na aftrek van alle verplichtingen' geldt het instrument als eigenvermogensinstrument. ${ }^{1}$ Een financieel instrument wordt geclassificeerd 'in overeenstemming met de economische realiteit van de contractuele overeenkomst' (IAS 32.15). Dit is in overeenstemming met het algemene uitgangspunt van 'substance over form' (Conceptual Framework 2.12): een verwerking of toelichting in de jaarrekening uitsluitend op grond van de juridische vorm leidt niet tot een getrouwe weergave indien de juridische vorm afwijkt van de economische realiteit.

Met een verwijzing naar de economische realiteit zijn lang niet alle vragen beantwoord, omdat in concrete situaties verschil van mening kan bestaan over de vraag wat deze realiteit dan precies is. IAS 32 biedt op onderdelen een nadere uitwerking die vrij algemeen, en ook door de IASB, niet als het definitieve antwoord wordt beschouwd. Er loopt dan ook een IASB-project over 'financial instruments with characteristics of equity' (FICE). In juni 2018 verscheen een discussion paper ${ }^{2}$ waarin de IASB in hoofdlijnen een nieuwe benadering schetste voor het maken van het onderscheid tussen eigen en vreemd vermogen. Tijdens het schrijven van dit artikel bezon de IASB zich nog op de te nemen vervolgstappen, naar aanleiding van het ontvangen commentaar op het discussion paper. Uit deze commentaren bleek dat de meeste belanghebbenden onderschrijven dat toepassing van IAS 32 tot diverse problemen kan leiden, en dat het daarom wenselijk is te zoeken naar oplossingen. Tegelijkertijd blijkt uit de ontvangen commentaren ook dat er nog geen consensus is over hoe die oplossingen er precies dienen uit te zien. ${ }^{3}$

\subsection{Nederlandse wet- en regelgeving}

In de wet wordt onderscheid gemaakt tussen eigen en vreemd vermogen. Het eigen vermogen wordt behandeld in artikel BW 2:373. Binnen het vreemd vermogen wordt onderscheid gemaakt tussen voorzieningen (artikel BW 2:374) en schulden (artikel BW 2:375). Als zodanig 
komt de term vreemd vermogen in de wet niet voor, wel de term eigen vermogen. Maar ook van eigen vermogen kent titel 9 géén definitie. In artikel 375 wordt opgenomen welke categorieën van eigen vermogen afzonderlijk moeten worden opgenomen, te weten:

a. het geplaatste kapitaal;

b. agio;

c. herwaarderingsreserves;

d. andere wettelijke reserves, onderscheiden naar hun aard;

e. statutaire reserves;

f. overige reserves;

g. niet-verdeelde winsten, met afzonderlijke vermelding van het resultaat na belastingen van het boekjaar, voor zover de bestemming daarvan niet in de balans is verwerkt.

Vervolgens worden nog enkele nadere voorschriften gegeven over kapitaal en reserves waaronder artikel BW 2:373, lid 3, 2:378, lid 2 en 2:385, lid 5 omtrent de verwerking van en toelichting op ingekochte eigen aandelen. Artikel BW 2:378 bevat nog enkele bepalingen over de toelichting op het eigen vermogen. Kort gezegd komt lid 1 erop neer dat een verloopoverzicht van de afzonderlijke posten van het eigen vermogen moet worden gegeven. Lid 2 verplicht tot uitsplitsing van de aandelen naar de verschillende soorten. Voorts dient op basis van lid 3 een opgave te worden gedaan van de wijze van storten op aandelen.

Deze bepalingen zullen niet tot problemen leiden zolang duidelijk is wat tot het 'kapitaal' of tot de 'aandelen' behoort. Maar het zijn juist de grenssituaties waar dit niet zo duidelijk is die tot vragen leiden. Een voorbeeld van zo'n grenssituatie zijn cumulatief preferente aandelen die wat betreft hun kasstroomprofiel weinig verschillen van achtergestelde leningen. Hierover geeft titel 9 geen uitsluitsel. Wel bevat BW 2: 391 lid 1 letter b het vereiste dat in de overige gegevens de statutaire bepalingen over de winstverdeling worden opgenomen. Deze bepalingen kunnen van belang zijn bij de vraag of er sprake is van eigen dan wel vreemd vermogen.

In tegenstelling tot de beknopte wettelijke bepalingen bevatten de Richtlijnen voor de Jaarverslaggeving (RJ) wel een uitgebreide behandeling van dit onderwerp. De bepalingen van de RJ zijn sterk beïnvloed door, maar niet identiek aan, de eerder geschetste benadering van IAS 32 (zie Camfferman 2019, voor een historisch overzicht van de aanpassingen in de RJ op dit punt naar aanleiding van IAS 32).

RJ 240 'Eigen vermogen' bevat afzonderlijke bepalingen voor de classificatie als eigen of vreemd vermogen in de geconsolideerde en in de enkelvoudige jaarrekening. Voor de geconsolideerde jaarrekening wordt verwezen (in RJ 240.302) naar RJ 290.8, onderdeel van het hoofdstuk 'Financiële instrumenten'. In RJ 290.801 vinden we in lijn met IAS 32 het algemene principe dat de classificatievanfinanciëleinstrumentenals eigen of vreemd vermogen in overeenstemming met de economische realiteit dient te zijn. Dit wordt in de daaropvolgende paragrafen nader uitgewerkt door te bepalen dat een instrument géén eigenvermogensinstrument is indien het een verplichting omvat om liquide middelen of een ander financieel actief aan een andere partij te leveren, of (met het oog op derivaten) een verplichting om financiële instrumenten met een andere partij te ruilen onder potentieel nadelige voorwaarden (RJ 290.801). Specifieke situaties zoals contracten die worden afgewikkeld in eigenvermogensinstrumenten van de uitgevende partij en samengestelde financiële instrumenten zoals converteerbare obligaties worden in het vervolg van RJ 290.8 nader behandeld, waarbij steeds het al dan niet bestaan (in termen van economische realiteit) van een verplichting bepalend is.

Het overnemen van een benadering op basis van economische realiteit in de $\mathrm{RJ}$ had als belangrijkste gevolg dat veel preferente aandelen niet langer als eigen vermogen geclassificeerd konden worden in de jaarrekeningen van Nederlandse ondernemingen. De Jong et al. (2006) hebben laten zien hoe dit leidde tot belangrijke verschuivingen in de schuldratio, en tot inkoop van preferente aandelen op aanzienlijke schaal.

Dat RJ 290 niet geheel conform IAS 32 is, blijkt onder meer hieruit dat preferente aandelen waarbij de dividenduitkering afhankelijk is van voldoende beschikbare winst naar keuze als eigen of vreemd vermogen behandeld kunnen worden (RJ 290.810). Onder IAS 32 is er in principe geen keuze, en zal sprake zijn van classificatie als vreemd vermogen wanneer de uitgevende onderneming géén discretionaire bevoegdheid heeft om al dan niet uitkeringen te doen (IAS 32.AG26).

Een specifiek onderwerp waarover in 2008 nadere bepalingen in IAS 32 zijn opgenomen, en sindsdien ook in de RJ, betreft aandelen waarop een inkoopverplichting rust, de zogenaamde puttable eigenvermogensinstrumenten. Hoewel dit per definitie financiële verplichtingen zijn, is het onder voorwaarden mogelijk deze toch als eigenvermogensinstrumenten te verwerken in de geconsolideerde jaarrekening (RJ 290.808). In paragraaf 4 gaan wij hier nader op in, omdat deze puttables onder andere bij coöperaties van belang kunnen zijn.

In de enkelvoudige jaarrekening is op grond van RJ 240.207 de juridische vorm van een financieel instrument bepalend voor de classificatie als eigen of vreemd vermogen, hetgeen dus in principe tot een verschillende classificatie in de enkelvoudige en geconsolideerde jaarrekening kan leiden. Als voorbeeld wordt genoemd: het aflossingsgedeelte van een verplicht converteerbare obligatie (RJ 240.207). Dit is naar de juridische vorm vreemd vermogen, maar naar de economische realiteit eigen vermogen. Het omgekeerde kan ook voorkomen, zoals de genoemde preferente aandelen. Hiervoor geldt dat separaat onder het eigen vermogen in de enkelvoudige jaarrekening het totaal van de financiële instrumenten dient te worden gepresenteerd die naar de economische 
realiteit als vreemd vermogen zouden worden verantwoord. Daarbij geldt dat voor ieder hieronder begrepen instrument de belangrijkste condities dienen te worden vermeld (RJ 240. 207). Een omgekeerde bepaling voor instrumenten met de juridische vorm van vreemd vermogen maar met de economische realiteit van eigen vermogen ontbreekt. ${ }^{4}$

In een nieuw ontwerp van RJ 240.207 wordt de classificatie in de enkelvoudige jaarrekening op basis van de juridische vorm niet meer verplicht gesteld maar als optie geboden. Deze ontwerpbepaling was nog niet van toepassing in het verslagjaar 2018.

Als er door verschil in classificatie een verschil ontstaat tussen het eigen vermogen volgens de enkelvoudige en volgens de geconsolideerde jaarrekening dient zo'n verschil volgens artikel BW2: 389, lid 10 in de toelichting bij de enkelvoudige jaarrekening te worden vermeld. Onder deze bepalingen vallen ook verschillen tussen enkelvoudig en geconsolideerd eigen vermogen uit hoofde van andere oorzaken die in het kader van dit artikel buiten beschouwing blijven, zoals minderheidsbelangen van derden en eliminatie van winsten op onderlinge leveringen.

\section{Selectie van onderzochte jaarrekeningen}

Zoals in paragraaf 1 aangegeven zijn twee afzonderlijke selecties van jaarrekeningen gemaakt.

Voor de eerste selectie is met behulp van de database Amadeus bepaald welke ondernemingen volgens de meest recente cijfers voldeden aan de criteria voor grote dan wel middelgrote rechtspersonen. Wij laten microentiteiten en kleine rechtspersonen buiten beschouwing in de veronderstelling dat bij veel van deze rechtspersonen de vermogensstructuur dermate simpel is dat dit niet tot grote verslaggevingsvraagstukken leidt. Voor zover deze vraagstukken zich voordoen, bijvoorbeeld in de vorm van leningen verstrekt door een directeur/grootaandeelhouder, zal het eerder gaan om vraagstukken in de fiscale sfeer waarbij bovendien de mogelijkheid bestaat de jaarrekening op fiscale grondslagen op te stellen.

De groottecriteria zijn niet exact maar bij benadering toegepast door ondernemingen te selecteren met een omzet van 12 tot 40 miljoen euro, respectievelijk groter dan 40 miljoen euro. ${ }^{5}$ Uit beide groepen is een willekeurige steekproef getrokken van 30 ondernemingen. Van deze ondernemingen is met behulp van company.info begin mei 2019 de jaarrekening over 2018 (dan wel over een gebroken boekjaar 2017/2018) gezocht. Ondernemingen waarvan de jaarrekening nog niet was gedeponeerd zijn vervangen door willekeurige nieuwe trekkingen. ${ }^{6}$ Hetzelfde gold voor ondernemingen waarvan de jaarrekening (enkelvoudig en/of geconsolideerd) op basis van IFRS was opgesteld, en voor professionele dienstverleners. De lijst van ondernemingen waarvan de jaarrekening is onderzocht is te vinden in de Bijlage 1.
Voor de tweede selectie van professionele dienstverleners is met behulp van company.info vastgesteld welke ondernemingen in de bedrijfstakken 'accountantskantoren' en 'advocatenkantoren', respectievelijk met de rechtsvorm 'coöperaties' per begin juni 2019 hun jaarrekening over 2018 (dan wel het gebroken boekjaar 2017/2018) hadden gedeponeerd. Uit beide groepen is een steekproef van 10 ondernemingen getrokken, bij de professionele dienstverleners gesplitst in 5 accountantskantoren en 5 advocatenkantoren. Voor zowel coöperaties als professionele dienstverleners is een minimale omzet van $€ 12 \mathrm{~m}$ gehanteerd. Voor de professionele dienstverleners kwam dit criterium er in combinatie met de vereiste beschikbaarheid op neer dat alleen kantoren met landelijke naamsbekendheid zijn geselecteerd, in tegenstelling tot lokaal opererende ondernemingen met slechts één of enkele vennoten. Bij de coöperaties is als aanvullend criterium gehanteerd dat er daadwerkelijk sprake is van meerdere leden. Met andere woorden, enkele coöperaties die dochtermaatschappij zijn van een buitenlandse moeder, zijn buiten beschouwing gebleven.

Enkele professionele dienstverleners maken in hun juridische structuur gebruik van de coöperatievorm, bijvoorbeeld doordat de partners (via hun persoonlijke BV's) lid zijn van de coöperatie die vervolgens de aandelen bezit in de werkmaatschappij (NV of BV). Deze coöperaties zijn buiten de coöperatiesteekproef gehouden, maar hun jaarrekeningen, voor zover beschikbaar, zijn wel geraadpleegd bij het onderzoek van de jaarrekeningen van professionele dienstverleners. De lijst van onderzochte jaarrekeningen is te vinden in de Bijlage 1.

\section{Eigen en vreemd vermogen in de jaarrekening van (middel)grote ondernemingen}

\subsection{Afwijkende classificatie enkelvoudig/ geconsoli- deerd}

Het startpunt bij de behandeling van de jaarrekeningen van deze groep van 60 grote en middelgrote ondernemingen is de vraag of er verschillen voorkomen tussen het eigen vermogen in de geconsolideerde en in de enkelvoudige jaarrekening. Van de gedeponeerde 'jaarstukken' bevatten er 32 (53\%) zowel een enkelvoudige als een geconsolideerde jaarrekening. Van één onderneming bevat het gedeponeerde stuk alleen een geconsolideerde jaarrekening. Van de ondernemingen waarvan zowel een enkelvoudige als geconsolideerde jaarrekening beschikbaar is, tonen er zes een verschil tussen het enkelvoudige en geconsolideerde eigen vermogen. Deze verschillen worden veroorzaakt door minderheidsbelangen, deelnemingen met een negatief eigen vermogen en afwaardering op vorderingen op deelnemingen. Met andere woorden, er zijn géén situaties aangetroffen waarin de toepassing van RJ 240.207 en RJ 290.8 leidt tot een afwijkende classificatie 
van financiële instrumenten. Wel vermelden sommige ondernemingen in de toelichting op de enkelvoudige jaarrekening dat de classificatie van financiële instrumenten gebaseerd is op de juridische vorm, en in de toelichting op de geconsolideerde jaarrekening dat deze classificatie is gebaseerd op de economische realiteit. Dit leidt bij deze ondernemingen echter niet tot een verschil in classificatie tussen beide jaarrekeningen, en lijkt meer een indicatie te zijn van het gebruik van standaardteksten in de toelichting dan van een concrete classificatieproblematiek.

Voor ondernemingen die alleen een enkelvoudige jaarrekening publiceren is de juridische classificatie van RJ 240.207 van toepassing. Wel geldt dan als toelichtingsvereiste (RJ 240.102) dat een aansluiting moet worden gegeven tussen het eigen vermogen in de balans, op basis van de juridische vorm, en het eigen vermogen volgens 'de ter zake van toepassing zijnde bepalingen in de andere hoofdstukken', waarmee geduid wordt op de classificatie volgens economische realiteit (RJ 290.8). Een dergelijke toelichting is in géén van de 27 jaarrekeningen die alleen uit een enkelvoudige jaarrekening bestaan aangetroffen. Eén onderneming vermeldt in de toelichting op de waarderings- en resultaatbepalingsgrondslagen dat de classificatie als eigen vermogen gebaseerd is op de 'legal reality'. Dit kan wellicht volstaan als voorbeeld van toch vrij vaak voorkomende redactionele onzorgvuldigheden in deze gedeponeerde jaarrekeningen.

Deze bevindingen suggereren dat het door de RJ gemakte onderscheid in juridische vorm en economische betekenis hooguit voor een kleine minderheid van ondernemingen relevant is.?

\subsection{Eigenvermogensinstrumenten met verschillende rechten}

Er is een verschil denkbaar tussen situaties waarin er evident geen verschil is tussen economische realiteit en juridische betekenis van financiële instrumenten, en situaties waarin dit een grondiger afweging vraagt. Daarom hebben wij gezocht naar indicaties voor het bestaan van financiële instrumenten met mogelijk complexere classificatieproblematiek.

Indeeersteplaatshebbenwijgekekennaarhetvóórkomen van aandelen of andere eigenvermogensinstrumenten met uiteenlopende rechten. In gevallen waarin in de toelichting uitsluitend wordt vermeld dat 'het aandelenkapitaal is verdeeld in X gewone aandelen' (of vergelijkbare bewoordingen worden gebruikt) hebben wij verondersteld dat er géén sprake is van aandelen met verschillende rechten. In 14 jaarrekeningen (23\%) is sprake van aandelen of andere eigenvermogensinstrumenten met verschillende rechten. In één jaarrekening ontbreekt de toelichting op het eigen vermogen geheel, in een andere jaarrekening ontbreekt een expliciete toelichting op de samenstelling van het aandelenkapitaal. In de overige 44 jaarrekeningen wordt naar onze mening voldoende duidelijk gemaakt dat alle aandelen gelijke rechten hebben (zie Tabel 1). ${ }^{8}$

Gezien de diversiteit in aangetroffen aandelen met bijzondere rechten, en gezien de uiteenlopende kwaliteit
Tabel 1. Eigenvermogensinstrumenten met rechten afwijkend van gewone aandelen.

\begin{tabular}{lrr} 
& N & $\%$ \\
Ja, afwijkende financiële rechten & 9 & 15 \\
Ja, afwijkende zeggenschapsrechten & 1 & 2 \\
Ja, afwijkende financiële en zeggenschapsrechten & 2 & 3 \\
Ja, maar aard van rechten niet toegelicht & 2 & 3 \\
Geen informatie over samenstelling eigen vermogen & 2 & 3 \\
Geen instrumenten met afwijkende rechten & 44 & 74 \\
Totaal & 60 & 100 \\
\hline
\end{tabular}

van de toelichting hierop, moet de classificatie in Tabel 1 als indicatief worden beschouwd. Wel is duidelijk dat van gewone aandelen afwijkende rechten overwegend financieel van aard zijn. Dit wel zeggen dat het, onder verschillende benamingen, gaat om voorrangsrechten bij de verdeling van het resultaat. Dit 'preferent' dividend kan cumulatief zijn, en gemaximaliseerd. Het kan ook gaan om een 'primair' dividend waar bovenop nog eenzelfde uitkering als op de gewone aandelen wordt ontvangen. Ook is een situatie aangetroffen waarbij de winst uit specifieke activa toekomt aan de houders van een specifieke serie aandelen. In Tabel 1 wordt met 'afwijkende zeggenschapsrechten' gedoeld op rechten die houders van gewone aandelen niet hebben. In twee van de drie gevallen waarin dit aan de orde is betreft dit een instemmingsrecht bij specifieke beleidsbeslissingen. In het derde geval, een onderneming die een voetbalstadion exploiteert, gaat het om recht op zitplaatsen. ${ }^{9} \mathrm{Bij}$ de twee ondernemingen waar de aard van de rechten niet is toegelicht gaat het mogelijk ook om specifieke zeggenschapsrechten. Deze twee ondernemingen vermelden bij de overige gegevens de statutaire bepalingen omtrent winstverdeling zoals vereist in BW 2: 291 lid 1 letter b, maar hierin wordt géén melding gemaakt van de elders in de jaarrekening wel genoemde specifieke typen aandelen.

Voor zover er sprake is van aandelen met afwijkende winstrechten is niet altijd duidelijk of ook sprake is van afwijkende zeggenschapsrechten op andere terreinen dan resultaatbestemming en dividenduitkering. Slechts één onderneming vermeldt nadrukkelijk dat houders van preferente aandelen géén stemrecht hebben.

In het kader van dit artikel is de vraag van belang of in de jaarrekening voldoende aannemelijk wordt gemaakt dat financiële instrumenten anders dan gewone aandelen terecht als eigen vermogen zijn geclassificeerd. In Tabel 2 vatten wij de hiervoor relevante informatie kort samen voor de elf ondernemingen die informatie geven over eigenvermogensinstrumenten met afwijkende financiële rechten. De ondernemingen zijn in willekeurige volgorde in deze tabel opgenomen.

Als eerste kunnen wij hierbij opmerken dat in géén van de betreffende jaarrekeningen deze vraag expliciet aan de orde is gesteld. Met andere woorden, wij hebben géén jaarrekeningen aangetroffen waarin met zoveel woorden een mededeling wordt gedaan met de strekking: 'wij hebben deze instrumenten geclassificeerd als eigen vermogen omdat...' In vier van deze jaarrekeningen wordt wel in de uiteenzetting van de grondslagen een algemene opmerking 
Tabel 2. Informatie over eigen vermogensinstrumenten met bijzondere financiële rechten.

\begin{tabular}{|c|c|c|c|c|}
\hline Onderneming & Type instrument(en) & $\begin{array}{c}\text { Statutaire bepalingen } \\
\text { winstverdeling in overige } \\
\text { gegevens }\end{array}$ & $\begin{array}{l}\text { Informatie over winstrechten } \\
\text { in toelichting op post eigen } \\
\text { vermogen }\end{array}$ & $\begin{array}{l}\text { Algemene toelichting op } \\
\text { classificatie EV/VV in } \\
\text { uiteenzetting grondslagen }\end{array}$ \\
\hline A & $\begin{array}{c}\text { Aandelen met preferente, } \\
\text { gemaximaliseerde } \\
\text { dividenduitkering en } \\
\text { preferente, gemaximaliseerde } \\
\text { uitkering bij liquidatie }\end{array}$ & $\begin{array}{l}\text { Ja, inclusief bepalingen over } \\
\text { vereffening }\end{array}$ & $\begin{array}{c}\text { Nee, wel verwijzing naar } \\
\text { statutaire bepalingen in overige } \\
\text { gegevens }\end{array}$ & $\begin{array}{l}\text { Geconsolideerd economische } \\
\text { realiteit / enkelvoudig } \\
\text { juridische vorm }\end{array}$ \\
\hline B & $\begin{array}{c}\text { Achtergestelde } \\
\text { instrumenten gehouden } \\
\text { door moedermaatschappij; } \\
\text { terugbetaling op basis van } \\
\text { wederzijdse overeenstemming }\end{array}$ & $\begin{array}{c}\text { Ja, alleen winstverdeling; } \\
\text { geen informatie over dividend } \\
\text { of rente op achtergestelde } \\
\text { instrumenten }\end{array}$ & $\mathrm{Ja}$ & $\begin{array}{c}\text { Geconsolideerd: alleen } \\
\text { vermelding van gewone } \\
\text { aandelen / enkelvoudig geen } \\
\text { toelichting }\end{array}$ \\
\hline $\mathrm{C}$ & $\begin{array}{l}\text { Aandelen met niet-cumulatief, } \\
\text { gemaximaliseerd preferent } \\
\text { dividend }\end{array}$ & Ja, alleen winstverdeling & Nee & $\begin{array}{c}\text { Geconsolideerd } \\
\text { economische realiteit/ } \\
\text { enkelvoudig verwijzing naar } \\
\text { geconsolideerde toelichting }\end{array}$ \\
\hline $\mathrm{D}$ & $\begin{array}{l}\text { Aandelenkapitaal verdeeld in } \\
\text { twee series waarvoor algemene } \\
\text { vergadering verschillende } \\
\text { dividenduitkeringen kan } \\
\text { besluiten }\end{array}$ & Ja, alleen winstverdeling & Nee & $\begin{array}{c}\text { Nee. Niet in geconsolideerde } \\
\text { en niet in enkelvoudige } \\
\text { jaarrekening }\end{array}$ \\
\hline $\mathrm{E}$ & $\begin{array}{l}\text { Aandelen met niet-cumulatief, } \\
\text { gemaximaliseerd preferent } \\
\text { dividend }\end{array}$ & $\begin{array}{c}\text { Ja, maar geen vermelding van } \\
\text { preferente aandelen. Geen } \\
\text { informatie over vereffening }\end{array}$ & $\mathrm{Ja}$ & $\begin{array}{l}\text { Nee. Niet in geconsolideerde } \\
\text { jaarrekening en niet in } \\
\text { enkelvoudige jaarrekening. }\end{array}$ \\
\hline $\mathrm{F}$ & $\begin{array}{l}\text { Aandelenkapitaal verdeeld } \\
\text { in meerdere series, waarvan } \\
\text { sommige recht hebben op } \\
\text { winsten uit bepaalde activa }\end{array}$ & Ja, alleen winstverdeling & Nee & $\begin{array}{c}\text { Nee. Niet in geconsolideerde } \\
\text { en niet in enkelvoudige } \\
\text { jaarrekening }\end{array}$ \\
\hline G & $\begin{array}{l}\text { Aandelen met cumulatief, } \\
\text { gemaximaliseerd preferent } \\
\text { dividend. Uitkering } \\
\text { onderworpen aan instemming } \\
\text { houders gewone aandelen }\end{array}$ & $\mathrm{Ja}$, alleen winstverdeling & Nee & $\begin{array}{c}\text { Nee. Niet in geconsolideerde } \\
\text { en niet in enkelvoudige } \\
\text { jaarrekening }\end{array}$ \\
\hline $\mathrm{H}$ & $\begin{array}{l}\text { Aandelen met cumulatief } \\
\text { preferent, gemaximaliseerd } \\
\text { dividend. }\end{array}$ & Ja, alleen winstverdeling & $\mathrm{Ja}$ & $\begin{array}{c}\text { Nee. Niet in geconsolideerde } \\
\text { en niet in enkelvoudige } \\
\text { jaarrekening }\end{array}$ \\
\hline I & $\begin{array}{l}\text { Aandelen met cumulatief, } \\
\text { gemaximaliseerd preferent } \\
\text { dividend }\end{array}$ & $\begin{array}{l}\text { Ja, alleen winstverdeling. } \\
\text { Geen vermelding van het } \\
\text { cumulatieve karakter van } \\
\text { preferent dividend }\end{array}$ & $\begin{array}{c}\text { Ja, informatie over achterstand } \\
\text { in cumulatief preferent } \\
\text { dividend }\end{array}$ & $\begin{array}{c}\text { Nee. Niet in geconsolideerde } \\
\text { en niet in enkelvoudige } \\
\text { jaarrekening. }\end{array}$ \\
\hline $\mathrm{J}$ & $\begin{array}{l}\text { Aandelen met niet-cumulatief } \\
\text { gemaximaliseerd dividend }\end{array}$ & Ja, alleen winstverdeling & Nee & $\begin{array}{l}\text { Geconsolideerd economische } \\
\text { realiteit / enkelvoudig } \\
\text { juridische vorm }\end{array}$ \\
\hline $\mathrm{K}$ & $\begin{array}{l}\text { Aandelen met niet-cumulatief, } \\
\text { gemaximaliseerd dividend }\end{array}$ & Ja, alleen winstverdeling & Nee & Nee \\
\hline
\end{tabular}

gemaakt over classificatie als eigen of vreemd vermogen, maar deze wordt in geen van deze jaarrekeningen concreet toegepast op de desbetreffende financiële instrumenten.

Het is dus aan de lezer zelf om deze vraag te stellen en op zoek te gaan naar relevante informatie. Voor zover deze wordt verstrekt gebeurt dit in de toelichting op de samenstelling van het eigen vermogen (in de enkelvoudige of geconsolideerde jaarrekening) en/ of in de statutaire bepalingen over winstverdeling die op grond van BW2: 392 lid 1 letter b als onderdeel van de overige gegevens aan de jaarrekening worden toegevoegd. Deze statutaire bepalingen worden door alle elf ondernemingen letterlijk gegeven of samengevat, maar hieruit blijkt niet altijd volledig welke bijzondere rechten aan eigenvermogensinstrumenten zijn verbonden. De in Tabel 2 als 'A' aangeduide onderneming geeft niet alleen de statutaire bepalingen met betrekking tot winstverdeling, zoals wettelijk vereist, maar ook de bepalingen inzake vereffening bij liquidatie. Voor het inzicht in de classificatie als eigen of vreemd vermogen is dat naar onze mening een zinvolle toevoeging.

De meeste situaties in Tabel 2 betreffen een vorm van aandelen met preferent dividend. Hiervoor geldt dat de classificatie als eigen dan wel vreemd vermogen volgens RJ 290.805 en 810 afhankelijk is van de vraag of er verplichtingen bestaan tot inkoop, dan wel verplichtingen tot winstonafhankelijke uitkeringen. Zoals eerder aangegeven bepaalt RJ 290.810 dat uitkeringen die afhankelijk zijn van voldoende uitkeerbare winst, hoewel zij bij preferente aandelen het karakter kunnen hebben van voorwaardelijke verplichtingen, feitelijk wezenskenmerken van eigen vermogen zijn. De RJ geeft aan dat instrumenten met dergelijke uitkeringen naar keuze van de rechtspersoon als eigen of vreemd vermogen geclassificeerd kunnen worden. Deze keuze wordt in de toelichting uiteengezet.

De meeste preferente aandelen in Tabel 2 lijken het karakter te hebben van dergelijke voorwaardelijke verplichtingen. Slechts in een enkel geval, waarin naast 
voldoende winst als extra voorwaarde ook instemming van de houders van gewone aandelen vereist is, lijkt ondubbelzinnig sprake te zijn van eigen vermogen (hoewel ook in dit geval in principe de mogelijkheid bestaat dat de houders van preferente aandelen tevens een meerderheid van de gewone aandelen houden, zodat de aanvullende voorwaarde van instemming door de gewone aandeelhouders geen substantiële betekenis heeft). In alle andere gevallen is dus in wezen gebruik gemakt van de keuzemogelijkheid van RJ 290.810, maar is dit in geen van deze gevallen toegelicht.

Zoals verder uit Tabel 2 blijkt, is bij één onderneming (aangeduid als 'B') sprake van instrumenten die zowel in de enkelvoudige als in de geconsolideerde jaarrekening als eigen vermogen geclassificeerd zijn. Dit betreft geen aandelen, maar een vorm van financiering die is achtergesteld ten opzichte van alle verplichtingen. In onze steekproef lijkt dit de situatie te zijn waarin de classificatiebeslissing zowel enkelvoudig (op basis van juridische vorm) als geconsolideerd (op basis van economische realiteit) het minst evident is, en dus het meest vraagt om nadere toelichting. Vermeld wordt dat over deze instrumenten géén rente wordt vergoed. Ook wordt aangegeven dat de instrumenten, na een genoemd aantal jaren, op basis van wederzijdse overeenstemming kunnen worden afgelost. In principe is de 'wederzijdse overeenstemming' van belang bij de vraag of deze instrumenten als eigen vermogen geclassificeerd kunnen worden. Indien de rechtspersoon een inkoop kan tegenhouden is immers geen sprake van een verplichting. In dit geval is het echter zo dat de houder van de instrumenten tevens eigenaar is van alle gewone aandelen en volledige zeggenschap heeft over de rechtspersoon. Dit maakt het ingewikkeld om het perspectief van de rechtspersoon te scheiden van het perspectief van de houder van de financiële instrumenten, en dus om te bepalen of sprake is van een verplichting. Daarnaast kan men opmerken dat RJ 290 (en IAS 32) niet uitsluitend zijn gericht op het bestaan van een verplichting, hoe zwaar deze factor ook weegt. De definitie van eigen vermogen omvat ook het aspect van 'residual interest'. In het hier besproken geval heeft de houder van het desbetreffende financiële instrument waarschijnlijk géén recht op uitkering van meer dan de nominale waarde, en daarmee geen 'residual interest'. De vraag is dan of men alles wat geen 'residual interest' is tot de verplichtingen rekent, of dat men aan de vraag of iets een 'residual interest' is niet meer toekomt nadat is vastgesteld dat er geen sprake is van een verplichting. In dit specifieke geval is er ook de vraag of men het gehele belang van de eigenaar, ongeacht de juridische vorm, mag beschouwen als een 'residual interest'.

Dit type vragen zijn voorbeelden van de conceptuele problematiek waar het FICE-project van de IASB een antwoord op wil zoeken, en waar dus niet zonder meer eenduidige antwoorden in de huidige versies van RJ 290 en IAS 32 op te vinden zijn. Overigens biedt ook RJ 240 niet veel houvast bij de vraag of er ook financiële instrumenten kunnen bestaan die géén aandelen zijn maar wel de juridische vorm hebben van eigen vermogen.
De reden om deze situatie wat uitgebreider te bespreken is dan ook niet zozeer om de keuze van deze onderneming ter discussie stellen, waartoe ons ook de benodigde informatie ontbreekt, maar om te laten zien hoe het belang van een goede toelichting op de gemaakte keuze zeer snel kan toenemen zodra men buiten de gangbare situaties en de in RJ 290.8 behandelde voorbeelden terecht komt.

\subsection{Vreemdvermogensinstrumenten met kenmerken van eigen vermogen}

Het aan het eind van de vorige subparagraaf besproken voorbeeld wijst in de richting van financiële instrumenten met de juridische vorm van vreemd vermogen maar met kenmerken van eigen vermogen. Zoals aangegeven zijn wij binnen het eigen vermogen vrijwel geen voorbeelden tegengekomen van dit type instrumenten. Wij veronderstellen ook dat, voor zover er twijfel over de classificatie van dergelijke instrumenten kan bestaan, zij bij voorkeur in het eigen vermogen worden verwerkt. Toch hebben wij volledigheidshalve ook gekeken of er sprake is van onder het vreemd vermogen geclassificeerde instrumenten met kenmerken van eigen vermogen. Voor onze steekproef betekent dit dat wij gekeken hebben naar achtergestelde leningen, en in het bijzonder achtergestelde leningen verstrekt door verbonden partijen. Deze zijn zeker niet zonder meer te classificeren als eigen vermogen, maar het is denkbaar dat een niet-aflosbare renteloze lening, of een lening met winstafhankelijke rente, in termen van economische realiteit het karakter aanneemt van eigen vermogen.

$\mathrm{Bij}$ in totaal acht ondernemingen is, binnen het vreemd vermogen, sprake van achtergestelde leningen (zie tabel 3).

Tabel 3. Achtergesteld vreemd vermogen.

\begin{tabular}{lrr} 
& n & $\%$ \\
Ja, achtergestelde leningen van aandeelhouders of & 3 & 5 \\
verbonden partijen & & \\
Ja, van andere genoemde partijen & 3 & 5 \\
Ja, achtergestelde leningen van onbekende partij & 1 & 2 \\
Ja, maar niet nader toegelicht & 1 & 2 \\
Geen melding van achtergesteld vreemd vermogen & 52 & 86 \\
Totaal & 60 & 100 \\
\hline
\end{tabular}

Wij merken op dat toelichting op eventuele achterstelling verplicht is op grond van BW2:375 lid 4, maar dat hier niet uit volgt dat ondernemingen verplicht dienen te bevestigen dat géén sprake is van achterstelling. In de meeste situaties waarin geen melding wordt gemaakt van achterstelling is ook geen aanleiding om achterstelling te veronderstellen, bijvoorbeeld omdat het vreemd vermogen uitsluitend bestaat uit voorzieningen en kortlopende schulden.

Op basis van de verstrekte informatie is er geen aanleiding om de achtergestelde leningen van niet-verbonden genoemde partijen anders dan als vreemd vermogen te beschouwen. De lening van een niet-genoemde partij is een lening met een winstafhankelijke rentevergoeding maar een vastgestelde aflossingsdatum. De niet-toegelichte lening betreft een klein bedrag. De drie situaties van leningen door aandeelhouders of verbonden partijen betreffen: 
- Leningen van het groepshoofd en een tussenholding. In de toelichting wordt melding gemaakt van rente en aflossing, maar ook van conversie van een deel van een dergelijke lening in kapitaal.

- Leningen van gelieerde maatschappijen, met achterstelling ten opzichte van alle andere verplichtingen. Deze leningen hebben een vaste rente en een looptijd van meestal niet meer dan vijf jaar.

- Een rente- en aflossingsvrije lening van het groepshoofd.

Op basis van deze informatie kan geconcludeerd worden dat achtergestelde leningen op beperkte schaal voorkomen. Voor een deel van deze leningen hoeft waarschijnlijk geen twijfel te bestaan over classificatie als vreemd vermogen. In een enkel geval vraagt de classificatie waarschijnlijk wel om enige overweging. De situatie van een achtergestelde lening van een groepshoofd zonder rente en aflossingsverplichtingen komt toch wel sterk in de buurt van de in paragraaf 4.2 besproken eigenvermogensinstrumenten zonder rentevergoeding en zonder vastgesteld inkoopmoment. Wij onderstrepen nogmaals het belang van een goede toelichting op een in dergelijke situaties gemaakte keuze.

\section{Eigen en vreemd vermogen in de jaarrekeningen van coöperaties en professionele dienstverleners}

Zoals aangegeven in de Inleiding richt het onderzoek van de jaarrekeningen van coöperaties en professionele dienstverleners zich in het bijzonder op de vraag hoe eventuele rechten van leden of partners bij uittreding in de jaarrekening worden verwerkt. Afhankelijk van de gekozen structuur kan hierbij sprake zijn van zogeheten puttable eigen-vermogensinstrumenten. Deze instrumenten die volgens de Richtlijnen nogal eens voorkomen bij coöperaties en open-end beleggingsfondsen bevatten een contractuele verplichting van de rechtspersoon om het financiële instrument terug te kopen. Dergelijke instrumenten leiden volgens de definitie in paragraaf 290.4 en de voorwaarden van alinea 802 tot een financiële verplichting. Deze puttable instrumenten mogen echter bij wijze van uitzondering als eigen vermogen worden gepresenteerd indien aan alle volgende kenmerken is voldaan (RJ 290.808):

a. het geeft de houder ervan bij liquidatie recht op een pro-rata deel van de netto activa;

b. het instrument is achtergesteld bij alle andere instrumenten;

c. al deze 'meest achtergestelde instrumenten' hebben identieke eigenschappen, ze zijn bijvoorbeeld allemaal puttable;

d. de rechtspersoon heeft geen andere financiële instrumenten of contracten waarbij:

1. de verwachte kasstromen uit deze instrumenten of contracten grotendeels gebaseerd zijn op het re- sultaat of de veranderingen in de netto activa van de rechtspersoon,

2. dit andere instrument of contract de resterende waarde van de puttable instrumenten grotendeels kan beperken of vastzetten.

De toepassing van de presentatie van puttable instrumenten als eigen vermogen moet in de toelichting worden vermeld.

Dat de verwerking van puttables als probleem wordt ervaren is van relatief recente datum. Aan het begin van deze eeuw werd IFRS, inclusief de toen nog jonge bepalingen van IAS 32, in veel landen voor het eerst op grote schaal toegepast. Daarbij werd duidelijk dat het eigen vermogen van sommige typen rechtspersonen geheel zou verdwijnen, of negatief zou worden, omdat op de eigenvermogensinstrumenten een inkoopverplichting rustte. Veel ondernemingen, waaronder de multinationaal opererende Nieuw-Zeelandse coöperatie Fonterra, hebben sterk om een oplossing bij de IASB aangedrongen (Camfferman and Zeff 2015, pp. 382-384). Deze oplossing, waarvan de bovengenoemde bepalingen uit RJ 290.808 zijn afgeleid, werd in 2008 in IAS 32 opgenomen.

Coöperaties zijn een bekend voorbeeld van rechtspersonen die mogelijk met puttables te maken hebben, maar deze situatie kan zich bij elke rechtspersoon voordoen wanneer aan houders van eigenvermogensinstrumenten contractuele rechten zijn verleend om deze instrumenten aan de rechtspersoon terug te verkopen. Dit wordt geillustreerd door een recente uitspraak van de Ondernemingskamer waarin het besluit tot vaststelling van de jaarrekening van GGN Holding NV over 2017 werd vernietigd. De Ondernemingskamer was van oordeel dat de jaarrekening tekortschoot in het vereiste inzicht met betrekking tot een verplichting tot inkoop van aandelen uit hoofde van een participantenovereenkomst (zie de annotatie van Knol 2019). Hoewel deze casus zich toespitste op de vraag of in de enkelvoudige jaarrekening de in te kopen aandelen op grond van hun juridische vorm als eigen vermogen gepresenteerd konden worden, kwam ook aan de orde dat de toepasselijkheid, of niet, van RJ 290.808 in de geconsolideerde jaarrekening in deze situatie een relevante vraag was.

\subsection{Coöperaties}

Coöperaties zijn een vorm van vereniging, en hebben leden. De rechten en plichten van de leden met betrekking tot het kapitaal van de coöperatie worden nader bepaald in de statuten of het huishoudelijk reglement en kunnen sterk uiteenlopen. Voor zover leden individuele belangen hebben in het kapitaal van de coöperatie worden deze doorgaans aangeduid als participaties. Aan participaties kunnen winstdelingsrechten zijn verbonden. Ook kan zijn bepaald dat leden hun participatie voor inkoop kunnen aanbieden aan de coöperatie, dan wel een uitkering ontvangen bij beëindiging van hun lidmaatschap. In dit opzicht kunnen participaties wezenlijk verschillen van aandelen in een naamloze of besloten vennootschap. Aan deze uittreding kunnen voorwaarden verbonden zijn. RJ 
620 'Coöperaties' bevat specifieke bepalingen voor de jaarrekening van coöperaties, waaronder met betrekking tot de classificatie van participaties als eigen of vreemd vermogen. Uitgangspunt hierbij zijn de reeds besproken algemene bepalingen van RJ 240.207 voor de enkelvoudige jaarrekening en RJ 290.8 voor de geconsolideerde jaarrekening (RJ 620.203). Voor de enkelvoudige jaarrekening betekent dit dus dat de juridische vorm bepalend is voor de classificatie. Wat dit betekent wordt niet verder toegelicht. Voor de geconsolideerde jaarrekening wordt wel nader aangeduid wat classificatie op basis van economische realiteit inhoudt. Dit gebeurt aan de hand van voorbeelden. Participaties waarvoor geen wettelijk of statutair verbod op terugbetaling bestaat worden verwerkt als vreemd vermogen (RJ 620.204). Een uitzondering kan worden gemaakt voor de eerder genoemde puttables.

Net als bij de onderzochte NVs en BVs zijn bij de coöperaties géén situaties aangetroffen waar het geconsolideerde eigen vermogen afwijkt van het eigen vermogen in de enkelvoudige jaarrekening, afgezien van het effect van minderheidsbelangen van derden. ${ }^{10}$ Een verschil tussen classificatie op basis van economische realiteit en juridische vorm doet zich dus niet voor.

Het algemene beeld dat uit de tien onderzochte jaarrekeningen van coöperaties naar voren komt is dat betalingen aan leden bij uittreding slechts beperkt voorkomen, maar dat hierover weinig en moeilijk vergelijkbare informatie wordt gegeven. Slechts één coöperatie besteedt in de algemene grondslagen van waardering en resultaatbepaling aandacht aan de post eigen vermogen, maar niet aan het onderwerp uittreding. Dit heeft er mogelijk mee te maken dat bij zeven van de tien onderzochte coöperaties de aansprakelijkheid van leden is uitgesloten ('U.A.'). De overige drie kennen beperkte aansprakelijkheid van de leden ('B.A.'). Bij uitgesloten aansprakelijkheid kan het lidmaatschap functioneren als aandeelhouderschap, waarbij ook geen mogelijkheid is om op individuele basis het gestorte kapitaal terug te vragen. Het is ook mogelijk dat het lidmaatschap tot stand komt zonder kapitaalstorting, en equivalent is aan het lidmaatschap van een gewone vereniging. Bij beperkte aansprakelijkheid ligt het wellicht meer voor de hand dat bij toe- en uittreding een kapitaalstorting en -uitkering plaatsvindt, hoewel dit niet rechtstreeks uit de beperkte aansprakelijkheid voortvloeit.

Tabel 4 laat zien dat zes coöperaties in de jaarrekening of het bestuursverslag (voor zover gedeponeerd) géén expliciete informatie geven over de ontwikkeling van het aantal leden. Bij vier van deze zes kan wel op basis van het mutatieoverzicht eigen vermogen worden vastgesteld

Tabel 4. Uittredende leden en mutaties in het eigen vermogen.

\begin{tabular}{l|c|c} 
& $\begin{array}{c}\text { Mutaties in eigen } \\
\text { vermogen als gevolg } \\
\text { van uittreding }\end{array}$ & $\begin{array}{c}\text { Geen mutaties in } \\
\text { eigen vermogen als } \\
\text { gevolg van uittreding }\end{array}$ \\
\hline $\begin{array}{l}\text { Informatie dat leden } \\
\text { zijn uitgetreden }\end{array}$ & 0 & 3 \\
\hline $\begin{array}{l}\text { Geen informatie over } \\
\text { uittredende leden }\end{array}$ & 2 & 4 \\
\hline $\begin{array}{l}\text { Bevestiging dat géén } \\
\text { leden zijn uitgetreden }\end{array}$ & n.v.t. & 1 \\
\hline
\end{tabular}

dat eventuele wijzigingen in het ledenaantal niet hebben geleid tot uitkering van eigen vermogen. Hetzelfde geldt voor drie coöperaties waarvan bekend is dat er leden zijn uitgetreden. In totaal drie coöperaties maken in de toelichting duidelijk dat het eigen vermogen, afgezien van de te verdelen jaarwinst, niet uitkeerbaar is.

Bij twee coöperaties, allebei met beperkte aansprakelijkheid, heeft het uittreden van leden wel gevolgen voor het eigen vermogen. Dit betreft de volgende situaties:

Een coöperatie waarvan het eigen vermogen grotendeels bestaat uit een 'ledenrekening' waar stortingen en onttrekkingen plaatsvinden anders dan uit hoofde van resultaatverdeling. In de toelichting worden deze stortingen en onttrekkingen niet nader toegelicht, anders dan door vermelding, met verwijzing naar de statuten, dat bij definitieve uittreding restitutie plaatsvindt. Het feit dat het saldo van de ledenrekening ondanks mutaties constant blijft op een rond bedrag lijkt er op te duiden dat bij uittreding vereist is dat een ander lid de participatie overneemt. Dit zou dan een belangrijke factor zijn bij de classificatie als eigen vermogen, omdat per saldo geen sprake is van een verplichting tot levering van liquide middelen of een ander financieel actief (RJ 290.802).

Een coöperatie waar in het eigen vermogen op de post 'gestort ledenkapitaal' mutaties plaatsvinden uit hoofde van 'storting nieuwe en bestaande leden' en 'mutatie naar terug te betalen ledenkapitaal'. Een post 'terug te betalen ledenkapitaal' is opgenomen onder de achtergestelde schulden. De mutaties in het gestorte ledenkapitaal salderen niet tot nul. Over de voorwaarden waaronder ledenkapitaal wordt terugbetaald wordt geen informatie gegeven. Mogelijk is hier sprake van puttable instrumenten, maar dit wordt niet toegelicht. Opgemerkt kan nog worden dat in het eigen vermogen ook een deel van het resultaat van het vorige boekjaar is opgenomen als 'reservering op naam' (dat wil zeggen: op naam van leden). Hierover wordt een vergoeding berekend van $4 \%$. Over eventuele opeisbaarheid van deze post wordt geen informatie verstrekt.

Het is wellicht begrijpelijk dat, wanneer bij een coöperatie geen uitkeringen aan uittredende leden kunnen vóórkomen, men niet snel op het idee komt hierover iets in de jaarrekening te zeggen. Maar omdat de lezer van de jaarrekening uit het gegeven van de rechtsvorm van de coöperatie veel minder gemakkelijk dan bij de NV of BV kan afleiden wat de status van het eigen vermogen is, zou het toch aanbeveling verdienen hier altijd enige toelichting over te geven. Bij coöperaties waarbij wel sprake kan zijn van uitkeringen aan uittredende leden of verplichte inkoop van participaties is goede toelichting uiteraard belangrijk. Bij presentatie van dergelijke participaties als eigen vermogen zou naar onze mening niet alleen een toelichting gegeven dienen te worden wanneer het gaat om puttables (zoals gevraagd in RJ 290.808), maar juist ook wanneer de entiteit van mening is dat géén sprake is van puttables.

\section{2 professionele dienstverleners}

Zoals aangegeven in paragraaf 3 zijn vijf advocatenkantoren en vijf grote accountantskantoren geselecteerd. Hierbij 
Tabel 5. Classificatie van partnerrechten in zakelijke dienstverleners.

\begin{tabular}{|c|c|c|}
\hline Onderneming & Structuur in hoofdlijnen & Classificatie partnerrechten \\
\hline A & $\begin{array}{l}\text { Operationele NV is eigendom van coöp met partner-BVs } \\
\text { als leden. Bij uittreding wordt door coöp een vast bedrag } \\
\text { uitgekeerd zonder verrekening met NV. NV publiceert } \\
\text { afzonderlijke jaarrekening, coöp publiceert geconsolideerde } \\
\text { jaarrekening inclusief operationele NV. }\end{array}$ & $\begin{array}{l}\text { In jaarrekening coöp (enkelvoudig en geconsolideerd) is } \\
\text { ledenkapitaal geclassificeerd als eigen vermogen. Hoewel } \\
\text { sprake lijkt te zijn van puttables is toepassing van RJ } 290.808 \\
\text { niet toegelicht. Uittreding heeft geen gevolgen voor eigen } \\
\text { vermogen NV. }\end{array}$ \\
\hline $\mathrm{B}$ & $\begin{array}{l}\text { Operationele NV is economisch eigendom van coöp, juridisch } \\
\text { eigendom bij partner BVs. Financiering door partners } \\
\text { hoofdzakelijk via financieringsstichting die achtergestelde } \\
\text { leningen aan NV verstrekt. Aandelen in NV worden bij toe/ } \\
\text { uittreding via financieringsstichting overgedragen. Jaarrekening } \\
\text { stichting niet beschikbaar. Coöp publiceert alleen enkelvoudige } \\
\text { jaarrekening. }\end{array}$ & $\begin{array}{l}\text { In jaarrekening coöp is ledenkapitaal geclassificeerd als } \\
\text { eigen vermogen op grond van 'juridische vorm'. Hoewel } \\
\text { waarschijnlijk puttable géén toelichting op eventuele } \\
\text { afwijkende classificatie op basis van economische realiteit. } \\
\text { Uittreding heeft geen gevolgen voor eigen vermogen NV. }\end{array}$ \\
\hline $\mathrm{C}$ & $\begin{array}{l}\text { Operationele coöp met partner-BVs als leden. Per lid vast } \\
\text { bedrag aan kapitaal in coöp. Daarnaast per lid achtergestelde } \\
\text { lening met omvang in overeenstemming met aandeel in } \\
\text { resultaat. Bij uittreding terugbetaling van zowel ledenkapitaal } \\
\text { als achtergestelde lening. }\end{array}$ & $\begin{array}{l}\text { In jaarrekening coöp (enkelvoudig en geconsolideerd) is } \\
\text { ledenkapitaal eigen vermogen en achtergestelde lening } \\
\text { vreemd vermogen. Hoewel sprake lijkt te zijn van puttables is } \\
\text { toepassing van RJ } 290.808 \text { niet toegelicht. }\end{array}$ \\
\hline D. & $\begin{array}{l}\text { Operationele NV met partner-BVs als aandeelhouders. } \\
\text { Daarnaast achtergestelde leningen per partner voor wisselende } \\
\text { bedragen in overeenstemming met aandeel in resultaat. Eigen } \\
\text { vermogen NV neemt toe/af door toe/uittredingen. }\end{array}$ & $\begin{array}{l}\text { In jaarrekening NV zijn aandelen geclassificeerd als eigen } \\
\text { vermogen, achtergestelde leningen als vreemd vermogen. } \\
\text { Toelichting meldt classificatie in geconsolideerde jaarrekening } \\
\text { op basis van economische realiteit en enkelvoudig op basis } \\
\text { van juridische vorm, maar geen verschil tussen enkelvoudig en } \\
\text { geconsolideerd. Aandelen in NV lijken puttable te zijn maar dit } \\
\text { wordt niet toegelicht. }\end{array}$ \\
\hline E. & $\begin{array}{l}\text { Operationele NV met beperkte informatie over } \\
\text { eigendomsstructuur. Geen mutaties in eigen vermogen } \\
\text { gedurende het boekjaar. Achtergestelde lening van een } \\
\text { financieringsstichting waarvan geen jaarrekening beschikbaar is. }\end{array}$ & $\begin{array}{l}\text { In jaarrekening NV worden aandelen enkelvoudig en } \\
\text { geconsolideerd geclassificeerd als eigen vermogen, } \\
\text { achtergestelde lening als vreemd vermogen. Geen nadere } \\
\text { toelichting. }\end{array}$ \\
\hline $\mathrm{F}$. & $\begin{array}{l}\text { Operationele NV is economisch eigendom van coöp, juridisch } \\
\text { eigendom bij partner-BVs. Financiering door partners } \\
\text { hoofdzakelijk via financieringsstichting die achtergestelde } \\
\text { leningen aan NV verstrekt. Alleen jaarrekening NV beschikbaar } \\
\text { (geconsolideerd op basis van IFRS, enkelvoudig op basis } \\
\text { van 'optie 3'), hierin coöp en stichting niet door consolidatie } \\
\text { opgenomen. }\end{array}$ & $\begin{array}{l}\text { In jaarrekening NV worden aandelen enkelvoudig en } \\
\text { geconsolideerd als eigen vermogen opgenomen. Mutaties } \\
\text { in aandelenkapitaal corresponderend met mutaties in } \\
\text { achtergestelde leningen als gevolg van toe- en uittreding wijzen } \\
\text { op puttable karakter aandelen, maar dit wordt niet toegelicht. }\end{array}$ \\
\hline G. & $\begin{array}{l}\text { Constant aandelenkapitaal in operationele NV (jaarrekening } \\
\text { gepubliceerd) wordt (indirect) gehouden door internationale } \\
\text { rechtspersoon. Financiering door partners middels } \\
\text { achtergestelde leningen via één of meer intermediaire } \\
\text { rechtspersonen (geen jaarrekening gepubliceerd) en een } \\
\text { coöperatie (jaarrekening gepubliceerd). Partners zijn leden } \\
\text { van een coöperatie die tevens beperkte zeggenschapsrechten } \\
\text { uitoefent in NV. }\end{array}$ & $\begin{array}{l}\text { In jaarrekening NV worden aandelen enkelvoudig en } \\
\text { geconsolideerd als eigen vermogen opgenomen. In jaarrekening } \\
\text { coöp (enkelvoudig en geconsolideerd) zijn ledenrechten } \\
\text { geclassificeerd als eigen vermogen. Deze lijken het karakter te } \\
\text { hebben van puttables, maar dit wordt niet toegelicht. }\end{array}$ \\
\hline H. & $\begin{array}{l}\text { Aandelen in operationele BV worden gehouden door coöp } \\
\text { waarvan partners lid zijn. Partners verstrekken ledenkapitaal } \\
\text { en leningen aan coöp. Jaarrekening van beide beschikbaar, BV } \\
\text { wordt door coöp geconsolideerd. }\end{array}$ & $\begin{array}{l}\text { In jaarrekening coöp (enkelvoudig en geconsolideerd) wordt } \\
\text { ledenkapitaal als eigen vermogen geclassificeerd. Mutaties door } \\
\text { toe- en uittreding wijzen mogelijk op puttables maar dit wordt } \\
\text { niet nader toegelicht. Geen mutaties in kapitaal BV. }\end{array}$ \\
\hline I. & $\begin{array}{l}\text { Aandelen in operationele NV worden gehouden door coöp. } \\
\text { Partners zijn leden van coöp. Coöp publiceert jaarrekening (op } \\
\text { basis van IFRS) waarin NV door consolidatie is opgenomen. }\end{array}$ & $\begin{array}{l}\text { In jaarrekening coöp zijn ledenrechten partners opgenomen als } \\
\text { vreemd vermogen met toelichting dat het puttable instrumenten } \\
\text { betreft die niet voldoen aan de vereisten voor classificatie als } \\
\text { eigen vermogen }\end{array}$ \\
\hline $\mathrm{J}$ & $\begin{array}{l}\text { Aandelen in operationele NV worden gehouden door coöp. } \\
\text { Partners zijn leden van coöp. Coöp publiceert jaarrekening (op } \\
\text { basis van IFRS) waarin NV door consolidatie is opgenomen. }\end{array}$ & $\begin{array}{l}\text { In jaarrekening coöp zijn ledenrechten partners opgenomen als } \\
\text { eigen vermogen met toelichting dat het puttable instrumenten } \\
\text { betreft die voldoen aan de vereisten voor classificatie als eigen } \\
\text { vermogen }\end{array}$ \\
\hline
\end{tabular}

is gezocht naar relatief grote ondernemingen met een partnerstructuur. Bij alle ondernemingen is sprake van partners die (via individuele partner-BVs die hier verder buiten beschouwing blijven) op een of andere wijze risicodragende financiering verschaffen aan een operationele holding waarbinnen de eigenlijke bedrijfsactiviteiten plaatsvinden. Deze financiering wordt bij uittreding gerestitueerd. Sommige onderzochte kantoren hebben een relatief complexe juridische structuur waarbij tussen de partner-BV's en de operationele holding één of meer rechtspersonen zoals een coöperatie en/of een stichting zijn geplaatst, bijvoorbeeld om fiscale redenen, of om de overdracht van belangen tussen toe- en uittredende partners te faciliteren. Deze 'intermediaire' rechtspersonen tussen de partner-BV's en de operationele holding worden soms wel, soms niet opgenomen in een geconsolideerde jaarrekening waarin ook de operationele holding is betrokken. Soms worden afzonderlijke jaarrekeningen gepubliceerd, maar niet in alle gevallen. De relaties tussen de holding, de 'intermediaire' rechtspersonen en de partner-BV's worden vastgelegd in toetredingsover- 
eenkomsten of vergelijkbare contracten waarvan de inhoud vaak min of meer summier wordt aangeduid, maar waarvan het bestaan soms slechts kan worden vermoed. Bij sommige accountantskantoren doet zich nog de aanvullende complicatie voor van internationale holdings die zeggenschap en/of financiering delen met de Nederlandse partners.

Een eerste observatie is dan ook dat het niet eenvoudig is om te spreken over 'de jaarrekening' van deze professionele dienstverleningsorganisaties omdat er sprake kan zijn van verschillende jaarrekeningen die samen een beeld geven van de financiële relaties tussen de partners en de operationele holding. Voor dit artikel is dan nog van belang dat de verschillende voor één organisatie relevante jaarrekeningen op basis van verschillende grondslagen (IFRS of Nederlandse grondslagen) kunnen zijn opgesteld. Dit doet zich niet voor bij de advocatenkantoren, die uitsluitend Nederlandse grondslagen toepassen, maar wel bij de accountantskantoren. Hoewel dit artikel zich in principe alleen richt op jaarrekeningen op basis van Nederlandse grondslagen bevat deze specifieke groep ook enkele ondernemingen waarvan de relevante verslaggeving grotendeels op basis van IFRS is gebaseerd.

De tweede en voornaamste observatie met betrekking tot deze groep is dat het veelal niet eenvoudig is om inzicht te krijgen in hoeverre de financiële relaties tussen de partners enerzijds en de operationele holding anderzijds in wezen het karakter hebben van verschaffing van eigen dan wel vreemd vermogen en, meer specifiek, of sprake is van puttable eigenvermogensinstrumenten. De redenen voor deze moeilijkheid zijn voor elke onderneming weer anders omdat zij samenhangen met de specifieke juridische structuur en de mate waarin deze wordt toegelicht. Tabel 5 geeft een samenvatting van de bevindingen.

De bevindingen in Tabel 5 kunnen als volgt worden samengevat: bij negen van de tien ondernemingen is of lijkt er sprake te zijn van mutaties in aandelenkapitaal en/ of participaties in samenhang met toe- en uittreding van partners. Bij één onderneming is dit niet vast te stellen omdat het kapitaal in het boekjaar niet verandert en er verder geen toelichting wordt verstrekt. Dit duidt er op dat puttable eigenvermogensinstrumenten vrij vaak voorkomen. Slechts twee ondernemingen, beide IFRS-toepassers en dus in zekere zin ten onrechte in de selectie opgenomen, bespreken puttable eigenvermogensinstrumenten, en de classificatie daarvan, met zoveel woorden in de toelichting.

\section{Conclusies}

Bij voorbaat was te verwachten dat classificatie van financiële instrumenten als eigen of vreemd vermogen niet voor alle ondernemingen een even ingewikkeld vraagstuk is. Het onderzoek bevestigt ook dat deze vraag voor veel ondernemingen niet of nauwelijks speelt, maar dat in specifieke omstandigheden complexe vragen aan de orde kunnen zijn. Bij de opzet van het onderzoek is hiermee rekening gehouden door te werken met zowel een willekeurige als een gerichte steekproef. De beperking van dit onderzoek is daarmee tegelijk dat de representativiteit van de bevindingen als geheel moeilijk is vast te stellen. Het onderzoek heeft daarmee een verkennend karakter. Toch zien wij voldoende grond om enkele conclusies te trekken.

Bij de grote en middelgrote ondernemingen lijkt complexe classificatieproblematiek weinig voor te komen zodat hier in de meeste jaarrekeningen ook terecht weinig of geen aandacht aan wordt besteed. Toch kunnen classificatievragen zich voordoen, en juist in deze uitzonderingssituaties neemt de behoefte aan entiteitsspecifieke toelichting snel toe.

Bij de coöperaties is de toelichting op het eigen vermogen doorgaans summier, ondanks dat de lezer van de jaarrekening uit de rechtsvorm niet direct kan afleiden of er sprake is van inkoopverplichtingen met betrekking tot participaties. Het is mogelijk dat bij veel coöperaties dergelijke verplichtingen niet aan de orde zijn, maar ze komen zeker voor en het is voor de lezer niet eenvoudig om het verschil te zien tussen coöperaties waar dit wel en niet het geval is.

Waar de juridische structuur van de onderzochte 'gewone' coöperaties niet bijzonder complex is, is dit bij de meeste onderzochte professionele dienstverleners wel het geval. De kwaliteit van de verslaggeving hierover hebben wij als zeer wisselend ervaren. Het is in veel gevallen niet eenvoudig om een duidelijk beeld te krijgen van de financiële verhoudingen tussen de partners en de operationele entiteit. Op basis van de beschikbare informatie lijken puttable eigenvermogensinstrumenten vaak voor te komen, zo niet bij de operationele entiteit zelf dan wel bij een 'intermediaire' rechtspersoon (vaak een coöperatie). Slechts bij enkele ondernemingen vonden wij echter een expliciete bespreking van de vraag of deze instrumenten als eigen dan wel vreemd vermogen worden behandeld.

Het onderscheid dat tot nu in de Richtlijnen voor de Jaarverslaggeving wordt gemaakt tussen classificatie in de enkelvoudige jaarrekening op basis van juridische vorm en in de geconsolideerde jaarrekening op basis van economische realiteit lijkt slechts een theoretisch onderscheid te zijn in de zin dat wij geen voorbeelden hebben aangetroffen van een afwijkende classificatie. Wel vonden wij in enkele toelichtingen op waarderingsgrondslagen een weerklank van deze RJ-bepaling, maar zonder praktisch effect op de jaarrekening is niet duidelijk of het hier gaat om 'boilerplate' of dat er bij het opstellen van de jaarrekening daadwerkelijk is stilgestaan bij een eventueel verschil tussen economische realiteit en juridische vorm.

Wij opperen het vermoeden dat classificatie als eigen of vreemdvermogenindepraktijkeenonderschatteproblematiek is, waardoor de beperkte situaties waarin classificatie niet evident is niet altijd als zodanig worden herkend. Mogelijk speelt hier een zekere inertie een rol: voordat de Richtlijnen onder invloed van IFRS werden aangepast was het immers gebruikelijk om vooral naar de juridische vorm te kijken, bijvoorbeeld wat betreft preferente aandelen. Ook houden wij het voor mogelijk dat er in de praktijk nog maar een beperkt bewustzijn is van de meer specifieke kwestie van de puttable eigenvermogensinstrumenten die in navolging van IFRS in de Richtlijnen aan de orde is gesteld. Wellicht dat de eerder genoemde uitspraak van de Ondernemingskamer inzake de jaarrekening van GGN Holding het bewustzijn op dit punt zal bevorderen. 
Prof. dr C. Camfferman is hoogleraar Financial Accounting aan de Vrije Universiteit Amsterdam.

- Prof. dr mr F. van der Wel is hoogleraar Externe Verslaggeving aan de Vrije Universiteit Amsterdam.

\section{Dankwoord}

De auteurs danken Barend Spanjers voor zijn bijdrage aan de gegevensverzameling voor dit artikel.

\section{Noten}

1. IAS 32.11. Opgemerkt wordt dat de Nederlandse vertaling spreekt van 'het overblijvende belang', waar het Engelse origineel ' $a$ residual interest' heeft. Hoewel geen verschil in betekenis bedoeld is, en het woord 'residual' op zichzelf al een zekere absolute lading heeft, laat de Engelse tekst de lezing open dat er verschillende eigenvermogensinstrumenten met verschillende soorten 'residual interests' naast elkaar kunnen bestaan.

2. DP/2018/1 'Financial Instruments with Characteristics of Equity'.

3. Zie bijvoorbeeld agenda paper 5E voor de IASB-vergadering van juli 2019. https://www.ifrs.org/-/media/feature/meetings/2019/july/iasb/ ap5e-fice.pdf

4. Dit neemt niet weg dat de algemene toelichtingsvereisten met betrekking tot financiële instrumenten uit RJ 290.9 van toepassing zijn. Met name het vereiste om rente- en liquiditeitsrisico toe te lichten zal in principe ook leiden tot relevante informatie over financiële instrumenten met de juridische vorm van vreemd vermogen maar met de economische realiteit van eigen vermogen.

5. Het is mogelijk dat hierdoor enkele ondernemingen ten onrechte als groot dan wel middelgroot zijn gekarakteriseerd. Wij hebben geen reden om aan te nemen dat dit de bevindingen wezenlijk heeft beïnvloed.

6. Hierdoor kan de steekproef enigszins vertekend zijn in de zin dat ondernemingen die hun jaarrekening later deponeren niet zijn opgenomen. Wij hebben geen aanleiding om te veronderstellen dat het deponeringstijdstip samenhangt met de complexiteit van de vermogensstructuur. Wel is denkbaar dat latere deponering samenhangt met een lagere kwaliteit van de toelichting. Opnemen van deze ondernemingen in de steekproef zou dan niet leiden tot andere conclusies.

7. Bij een steekproefomvang van $\mathrm{n}=59$ is de kans op het waargenomen resultaat ( 0 treffers) kleiner dan $1 \%$ wanneer in de populatie als geheel er bij $8 \%$ van de ondernemingen een verschil zou bestaan tussen 'economische' en 'juridische' classificatie, en kleiner dan $10 \%$ bij een trefkans van $4 \%$.

8. Voor de ondernemingen die in de toelichting alleen gewone aandelen noemen is nagegaan of de statutaire bepalingen omtrent winstverdeling, voor zover opgenomen onder de overige gegevens, nog aanwijzingen bevatten voor het bestaan van bijzondere rechten. Dit bleek niet het geval te zijn.

9. Het recht op zitplaatsen is op zichzelf geen financieel instrument. In hoeverre hiervoor een niet-financiële verplichting verantwoord zou moeten worden laten wij, ook vanwege het ontbreken van gedetailleerde informatie, rusten.

10. Zeven coöperaties geven (ook) een geconsolideerde jaarrekening, de overige drie alleen een enkelvoudige jaarrekening. Volledigheidshalve vermelden wij dat deze laatste drie geen aanvullende informatie verstrekken over eventuele verschillen tussen eigen vermogen op basis van juridische vorm en economische realiteit (RJ 240.102).

\section{Literatuur}

- Backhuijs JB (1994) Eigen en vreemd vermogen. Maandblad voor Accountancy en Bedrijfseconomie 68(1/2): 18-25. https://doi. org/10.5117/mab.68.13997

- Backhuijs JB, Camfferman K, Oudshoorn L (2017) Other comprehensive income: betekenis en presentatie in jaarrekeningen van Nederlandse Beursfondsen. Maandblad voor Accountancy en Bedrijfseconomie 91(11/12): 344-362. https://doi.org/10.5117/mab.91.24063

- Camfferman C (2019) Eigen vermogen en vreemd vermogen in de enkelvoudige jaarrekening volgens de Richtlijnen voor de jaarverslaggeving. Tijdschrift voor Jaarrekeningenrecht 14(2): 77-82.

- Camfferman C, Zeff SA (2015). Aiming for global accounting standards: the International Accounting Standards Board, 20012011. Oxford University Press. https://doi.org/10.1093/acprof:oso/9780199646319.001.0001

- De Jong A, Rosellón M, Verwijmeren P (2006) De invloed van IFRS op preferente aandelen in Nederland. Maandblad voor Accountan- cy en Bedrijfseconomie 80(7/8): 336-342. https://doi.org/10.5117/ mab. 80.20821

- International Accounting Standards Board [IASB] (2018) Discussion paper DP 2018/1. Financial instruments with characteristics of equity. https://www.ifrs.org/projects/work-plan/financial-instruments-with-characteristics-of-equity/\#published-documents

- Knol AN (2019) Annotatie OK-beschikking jaarrekeningprocedure GGN Holding N.V. Tijdschrift voor Jaarrekeningenrecht 14(2): 87-93.

- Van Geffen C, Kamp B (2017) De enkelvoudige jaarrekening van organisaties van openbaar belang. Maandblad voor Accountancy en Bedrijfseconomie 91(11/12): 302-404. https://doi.org/10.5117/ mab.91.24066

- Vergoossen RGA (2006) Invloed van IFRSs op nettoresultaat en eigen vermogen. Maandblad voor Accountancy en Bedrijfseconomie 80(11): 550-561. https://doi.org/10.5117/mab.80.12808 


\section{Bijlage 1}

Onderzochte ondernemingen - grote en middelgrote
rechtspersonen

1. AGI van de Steeg B.V.

2. Altavia Sumis Marketing Services B.V.

3. Barenbrug Holding B.V.

4. Blauwhoed Holding B.V.

5. Blokker Holding B.V.

6. BMC Moerdijk B.V.

7. BT NEDERLAND N.V.

8. Caesar Groep Rotterdam B.V.

9. The Chocolate Family B.V.

10. CK Stores Netherlands B.V.

11. De Kok Beheer Hardinxveld B.V.

12. De Vries en Verburg Groep B.V.

13. Denso Europe B.V.

14. Determan Exploitatie van Detailzaken B.V.

15. Domino's Pizza Europe B.V.

16. EBS Public Transportation BV

17. Etro Vastgoedzorg B.V.

18. Euroma Holding B.V.

19. Foppen Holding B.V.

20. Fruity Line B.V.

21. Infomedics Groep B.V.

22. International Furan Chemicals B.V.

23. Ionbond Netherlands B.V.

24. Javandel B.V.

25. B.V. Kennemervis Groep

26. Kidkraft Holdings B.V.

27. Komori International (Europe) B.V.

28. Krinkels B.V.

29. Makita Nederland B.V.

30. MCLS Europe B.V.

31. Mitsubishi Electric R\&D Centre Europe B.V.

32. Mitsubishi Turbocharger and Engine Europe B.V.

33. Montagny B.V.

34. Naspers Services B.V.

35. Nikon Instruments Europe B.V.

36. Otto B.V.

37. Paragon Pet Products Europe B.V.

38. PHB Deventer B.V.

39. Probroed B.V.

40. PSV N.V.

41. Puzzle Holding B.V.

42. Qorvo Utrecht B.V.

43. Dr. Reddy's Research and Development B.V.

44. Ricardo Nederland B.V.

45. Rockwell Automation B.V.

46. Roda J.C. B.V.

47. Schoonenberg Hoorcomfort BV

48. SCREEN GP Europe B.V.

49. Seiko Nederland B.V.

50. Slagheek B.V.

51. Specsavers Holding B.V.

52. Stadion Feijenoord N.V.

53. Takko Nederland B.V.

54. N.V. Texels Eigen Stoomboot Onderneming

55. Thomas Cook Nederland B.V.

56. Tromp Group B.V.

57. Uniface B.V.

58. Unigarant N.V.

59. Wassenburg Medical B.V.

60. Yusen Logistics (Benelux) B.V.

\section{Onderzochte ondernemingen - coöperaties en professionele}

A. Coöperaties

1. Coöperatie AB Vakwerkgroep UA

2. Coöperatie Boer en Zorg BA

3. Zuivelcoöperatie Deltamilk BA

4. Coop Nederland UA

5. Coöperatieve Nederlandse Bloembollencentrale UA

6. Noord Nederlandse Coöperatie van Zorgorganisaties UA

7. C.I.V. Superunie BA

8. Koninklijke Coöperatieve Telersvereniging Zuidoost-Nederland UA

9. Coöperatieve Zuidelijke Aan- en Verkoopvereniging UA

10. Coöperatieve Zuivelinvesteerders UA

B. Professionele dienstverleners (aangeduid met handelsnaam)

1. Baker \& McKenzie

2. De Brauw Blackstone Westbroek

3. Deloitte

4. De Jong \& Laan

5. Houthoff

6. KPMG

7. Mazars Paardekooper Hoffman

8. NautaDutilh

9. PricewaterhouseCoopers

10. Stibbe 